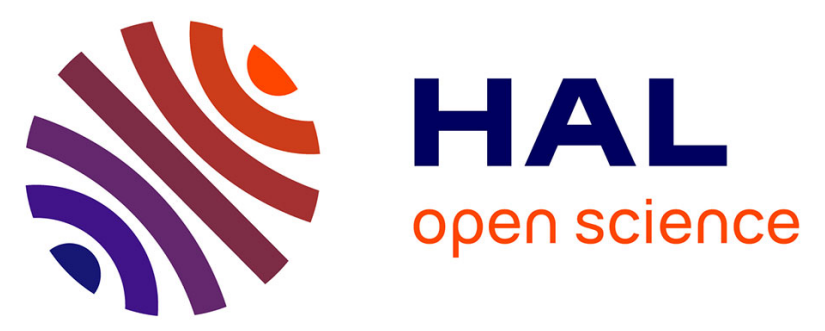

\title{
Biotransformation of guttiferones, Symphonia globulifera metabolites, by Bipolaris cactivora , an endophytic fungus isolated from its leaves
}

Pauline Menelle, Jérôme Quintin, Kevin Cottet, Yann Fromentin, Joëlle Dupont, Marie-Christine Lallemand, Didier Buisson

\section{To cite this version:}

Pauline Menelle, Jérôme Quintin, Kevin Cottet, Yann Fromentin, Joëlle Dupont, et al.. Biotransformation of guttiferones, Symphonia globulifera metabolites, by Bipolaris cactivora, an endophytic fungus isolated from its leaves. Organic \& Biomolecular Chemistry, 2021, 19 (6), pp.1378-1385. 10.1039/d0ob02443k . hal-03262416

\section{HAL Id: hal-03262416 https://hal.science/hal-03262416}

Submitted on 26 Nov 2021

HAL is a multi-disciplinary open access archive for the deposit and dissemination of scientific research documents, whether they are published or not. The documents may come from teaching and research institutions in France or abroad, or from public or private research centers.
L'archive ouverte pluridisciplinaire HAL, est destinée au dépôt et à la diffusion de documents scientifiques de niveau recherche, publiés ou non, émanant des établissements d'enseignement et de recherche français ou étrangers, des laboratoires publics ou privés. 
Received 00th January 20xx, Accepted 00th January 20xx DOI: $10.1039 / \times 0 \times x 00000 x$

\title{
Biotransformation of guttiferones, Symphonia globulifera metabolites, by Bipolaris cactivora, an endophytic fungus isolated from its leaves
}

\author{
Pauline Menelle, ${ }^{\mathrm{a}, \mathrm{b}}$ Jérôme Quintin, ${ }^{\mathrm{a}, \mathrm{b}, \mathrm{c}}$ Kevin Cottet, ${ }^{\mathrm{a}, \mathrm{b}}$ Yann Fromentin, ${ }^{\mathrm{a}, \mathrm{b}}$ Joëlle Dupont, ${ }^{\mathrm{d}}$ Marie- \\ Christine Lallemand ${ }^{\mathrm{a}}$ and Didier Buisson ${ }^{\mathrm{b} *}$
}

\begin{abstract}
The search for active microorganisms for the biotransformation of guttiferone $A(\mathbf{1})$ and $C$ (6) has been successfully undertaken from a collection of endophytic fungi of Symphonia globulifera. Of the twenty-five isolates obtained from the leaves, three are active and have been identified as Bipolaris cactivora. The products obtained are the result of xanthone cyclisation with the formation of two regioisomers among four possible and corresponding to 1,16-oxy-guttiferone and 3,16oxy-guttiferone. The biotransformation conditions were studied. Interestingly, both oxy-guttiferones $\mathrm{A}$ are present in the plant, and the ratio of 3,16-oxy-guttiferone to 1,16-oxy-guttiferone is $4: 1$, very close to that observed by biotransformation (3.8: 1). These results are consistent with the involvement of endophytes in their formation pathway from guttiferone $A$, in planta. Finally, biotransformation made it possible to obtain and describe for the first time oxy-guttiferones $\mathrm{C}$.
\end{abstract}

\section{Introduction}

Bioconversions i.e. the use of biological systems in organic synthesis, have become a toolbox widely used by chemists. Their interest in the production of high-value-added molecules is the chemo-, regio- and stereoselectivity in the enzymatically catalysed reaction. The counterpart of these selectivities is that for each transformation it is necessary to find the right biocatalyst. This research can be done by testing commercial and/or recombinant enzymes having the desired activity. Another approach is to test whole microorganisms. This approach has an advantage when the goal is to create molecular diversity ${ }^{1}$ as can be the case in pharmacochemistry and drug development. ${ }^{2}$ It should also be noted that this approach has highlighted original and unexpected enzymatic activities.

Screening an entire collection of microorganisms can be tedious as the ability of each microorganism to perform the desired biotransformation must be tested. Each test therefore requires (i) the cultivation of the microorganism under sterile conditions (ii) the incubation of biomass in the presence of the molecule to be transformed and (iii) monitoring of the biotransformation product

\footnotetext{
a. Unité PNAS UMR/CNRS CiTCOM N8038, Faculté de Pharmacie de Paris, Université de Paris, 4 avenue de l'observatoire, 75006 Paris, France.

b. Unité Molécules de Communication et Adaptation des Microorganismes (MCAM), Muséum national d'Histoire naturelle, CNRS, CP54, 57 rue Cuvier, 75005 Paris, France.

c. Centre d'Etudes et de Recherche sur le Médicament de Normandie, Normandie Université, UNICAEN, CERMN, 14000 Caen, France

d. Institut Systématique Evolution Biodiversité (ISYEB), Muséum national d'Histoire naturelle, CNRS, Sorbonne Université, EPHE, 57 rue Cuvier, CP39, 75005 Paris, France

+ Footnotes relating to the title and/or authors should appear here.

Electronic Supplementary Information (ESI) available: [details of any supplementary information available should be included here]. See DOI: 10.1039/x0xx00000x
}

formation. Several methods have been developed to optimize and make the procedures less time consuming.

The stages of micro-organism culture and incubations with the substrate can be carried out on small volumes and in this method, the use of microlitres plates allows automation. ${ }^{3}$ This leads to significant cost reductions and the possibility of conducting a large number of experiments simultaneously under similar conditions. However, the growing and incubation conditions are not always optimal especially for filamentous fungi because their mycelium occupies, after growth, the entire volume of the well. An other method is the implementation of the incubation phase using strain mixtures, which have previously been grown independently under good conditions. This methodology allows to reduce the number of assays and in the protocol that we have put in place the number of trials can be divided by three. ${ }^{4}$

Another microorganism selection approach is to look for strains living in contact with the molecule to be transformed. In this context, endophytic microorganisms are good candidates for the biotransformation of metabolites produced by their host plant. In one plant, many endophytic microorganisms coexist. They can be isolated, cultivated and identified, thus offering the opportunity to explore their own metabolism. They are surrounded by secondary metabolites produced by the host plant and adapt their enzymatic machinery to survive in this particular environment by metabolization. ${ }^{5}$ The literature describes many applications of biotransformations by endophytes but they mainly concern synthetic molecules. Examples involving metabolites produced by host plants of the endophytes include cinchona alkaloid, ${ }^{6}$ curcumin, ${ }^{7}$ cyclocanthogenol, ${ }^{8}$ diterpenes,${ }^{9}$ huperzine $A^{10}$ and huperzine $B,{ }^{11}$ mangostin, ${ }^{12}$ saponins, ${ }^{13}$ vinblastine ${ }^{14}$ or nigranoic acid derivatives. ${ }^{15}$

Our group investigates Symphonia globulifera, a tropical tree growing in Africa and South-America ${ }^{16}$ and described it as a source for biologically active secondary metabolites. ${ }^{17}$ Among them, 


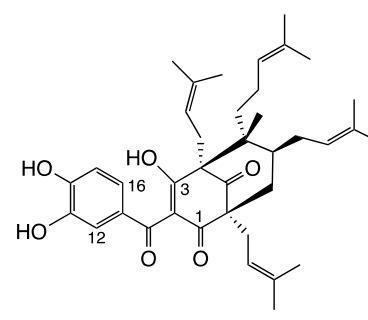

Guttiferone A 1

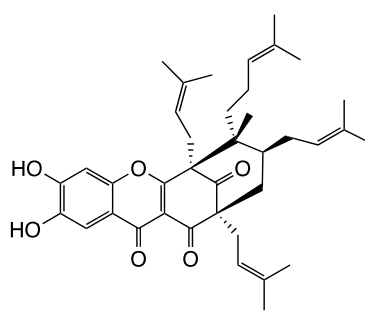

3,16-oxyguttiferone A 2

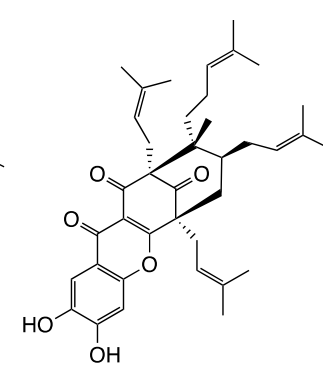

1,16-oxyguttiferone A 3

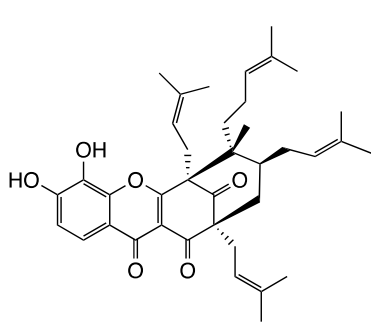

3,12-oxyguttiferone A 4

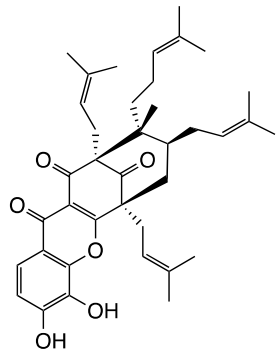

1,12-oxyguttiferone A 5

Fig. 1 Guttiferone A and oxy-guttiferones, the xanthone derivatives

guttiferone $A(\mathbf{1})$ shows a broad spectrum of activity, such as antiHIV ${ }^{18}{ }^{18}$ ytotoxic, ${ }^{19}$ trypanocidal, ${ }^{20}$ antiplasmodial, ${ }^{21}$ leishmanicidal, ${ }^{22}$ and antibacterial ${ }^{23}$ effects, and can be extracted on a gram scale. ${ }^{24}$ It belongs to the polycyclic polyprenyl acyl phloroglucinol family (PPAPs) which has been exclusively isolated from the plants of family Guttiferae. Some semisynthetic derivatives has been synthetized through the modification of catechol moiety and the phloroglucinol ring in order to reduce its toxicity and increase its antiparasitic activity. The chemical transformation of the catechol pattern ${ }^{25}$ made it possible to significantly decrease the toxicity with a modest impact on the anti-parasitic activity. However, xanthone (2) obtained by yeast-cyclization of guttiferone A (1) showed better activity against Plasmodium falciparum. ${ }^{26}$ This regio-selective cyclization is interesting since we reported ${ }^{27}$ that it is possible to obtain four xanthone-type-compounds with $3,16,1,16,3,12$ and 1,12 pattern corresponding to compounds $\mathbf{2 , 3 , 4}$ and $\mathbf{5}$ (Fig. 1) respectively. Our previous study of the biotransformation of guttiferone A also showed that only a few yeasts were effective and that the filamentous fungi from our collection were not able to transform this molecule. Thus, in order to obtain other guttiferone A derivatives, we chose to test endophytic microorganisms of $S$. globulifera. Here, we report the isolation of a $S$. globulifera endophytic strain. This latter was able to perform unusual PPAPs oxidation to biologically interesting and naturally occuring 3,16 and 1,16-oxy-guttiferone $\mathrm{A}$. This bioconversion ability has been used to generate chemical diversity via the synthesis of two new compounds from another PPAP, guttiferone C.

\section{Results and discussion}

\section{Endophytic isolates and identification of active fungus}

The fungal endophytes were isolated during a field trip to French Guiana from leaves of S. globulifera. The leaves were taken from the top of the tree and fragments of seven of them were deposited on solid culture medium (Potato-Dextrose-Agar) after surfacesterilisation to eliminate epiphytes using protocol described by Arnold. ${ }^{28}$ Twenty-five isolates were obtained and their ability to transform guttiferone $A(\mathbf{1})$ was tested. They were cultivated in liquid culture medium before addition of guttiferone A (1) and formation of metabolites was monitored by HPLC analysis. Three positive assays were obtained with formation of two known oxy-guttiferones, 3,16-oxy-guttiferone A (2) and 1,16-oxy-guttiferone A (3). The molecular identification of these isolates using ITSrDNA sequences indicated that the three are related to the species Bipolaris cactivora. ${ }^{29}$ It can be noted that these three isolates came from different leaves, demonstrating an occurrence of this fungus in $S$. globulifera. B. cactivora is an Ascomycete belonging to the Pleosporaceae family. The best hits from GenBank (KU232897, 100\% homology with our sequences) are mostly referred to endophytes specimens isolated from leaves of diverse tropical plants (Garcinia $\mathrm{sp}$, Myristica fragrans, Adansonia gregorii, Musa sp) or from seeds of Oryzae sativa in Malaysia and Thailand. Another Bipolaris strain ( $B$. sorokiniana) has been isolated from Symphonia globulifera. ${ }^{30}$

\section{Biotransformation conditions}

We then studied the incubation conditions because this fungus has never been described in biotransformation. Generally, they are controlled by incubation of microorganism in resting cells conditions, i.e. incubations with molecule to be transformed are not performed in culture medium. After growing, the cultures are filtered, the biomasses are resuspended in buffer and substrate is added. So, it was important to highlight a possible excretion of the involved enzyme(s). Indeed, hydroxybenzophenones cyclization can be catalyzed by two types of enzymatic activities, one corresponds to excreted enzymes such as oxidases, e.g. laccase from fungus Polystitus versicolor ${ }^{31}$ and the other to unexcreted enzymatic complexes such as cytochromes $\mathrm{P} 450 .{ }^{32}$ In order to assess that, guttiferone $A(\mathbf{1})$ was incubated in the growing medium after the biomass harvest. No reaction was observed in these conditions, while there was a biotransformation during incubation in the culture medium with the cells and in resting cells conditions. These results showed the enzymatic activity responsible for the cyclization is not excreted from the mycelium of the fungus, in contrary to that observed in yeast biotransformation previously described. ${ }^{26}$ Indeed, we reported the formation of 3,16-oxy-guttiferone A (2) by an enzyme produced by yeast Rhodotorula buffonii (renamed as Pseudohyphozyma buffonii) and excreted in culture medium.

During the biotransformation, the residual metabolism may modify $\mathrm{pH}$, in particular in buffer with relatively low concentration, with its increase or decrease depending on the microorganisms. However, to the extent that such cyclization was observed for benzophenone under certain conditions (basic $\left.\mathrm{pH}, 100^{\circ} \mathrm{C}\right)^{33}$ it was

Table 1 Influence of $\mathrm{pH}$ on the stability of guttiferone $\mathrm{A}$ and C. Relative percent of products in sterile buffer after four days at $27^{\circ} \mathrm{C}$.

\begin{tabular}{cccccccc}
\hline substrates & \multicolumn{3}{c}{ Guttiferone A } & & \multicolumn{3}{c}{ Guttiferone C } \\
\cline { 2 - 4 } \cline { 6 - 8 } Products & $\mathbf{1}$ & $\mathbf{2}$ & $\mathbf{3}$ & & $\mathbf{6}$ & $\mathbf{7}$ & $\mathbf{8}$ \\
\hline $\mathrm{pH} 6$ & 100 & $<1$ & $<1$ & & 100 & $<1$ & $<1$ \\
$\mathrm{pH} 7$ & 93 & 7 & 0 & & 98 & 2 & $<1$ \\
$\mathrm{pH} 8$ & 81 & 16.5 & 2.5 & & 84 & 8 & 8 \\
\hline
\end{tabular}




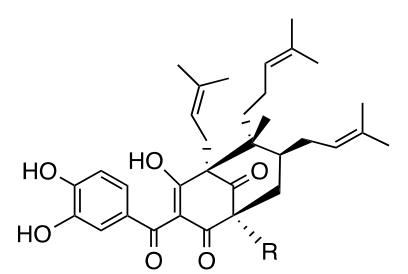

Guttiferone<smiles>C=C(CCC(CC(C)=CC)C(=C)C)P=P</smiles>

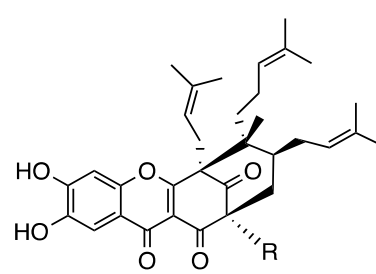

3,16-oxyguttiferone

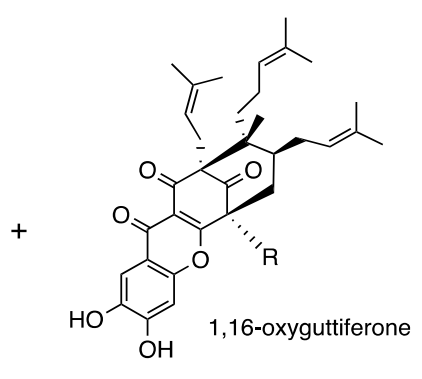

$3: 12 \%$

6 days

Scheme 1 Biotransformation of guttiferone A (1) and guttiferone C (6) by the endophytic fungus $B$. cactivora LCP 6370

important to check the influence of $\mathrm{pH}$ on the stability of guttiferones at incubation temperature $\left(27^{\circ} \mathrm{C}\right)$. During control experiments, guttiferones were incubated in buffer without microorganism, it was shown that the cyclisation occurs in basic media. The conversion rate is related to the $\mathrm{pH}$ value as shown in table 1 , with a $\mathrm{pH}$ value of 6 or below only trace were detected while at $\mathrm{pH} 7$ and 8 the conversion rate was 7 and $19 \%$ respectively. Similar results were obtained with guttiferone $\mathrm{C}$, the new products formed $\mathbf{7}$ and $\mathbf{8}$ were identified by comparing with products obtained by biotransformation of guttiferone $\mathrm{C}(6)$ (see below). Under these conditions and at $\mathrm{pH} 8$, 3,16-oxy-guttiferones $(2,7)$ and 1,16-oxy-guttiferones $(3,8)$ were observed with ratio for oxy-guttiferone $A \mathbf{2} / \mathbf{3}$ of $6.6: 1$ and for oxyguttiferone $C 7 / 8$ of $1: 1$. These ratio were different from those observed during bioconversions (see below).

\section{Production of oxy-guttiferones}

These unexpected stability issue led, in order to observe only the biotransformation reactions, to carry out all the manipulations at $\mathrm{pH}$ 6. This excluded spontaneous cyclization in incubation medium and therefore only microorganism action can be claimed moreover the controls without microorganism have clearly shown the stability of the two guttiferones.

During the 7 days of biotransformation assays in the presence of B. cactivora, the $\mathrm{pH}$ had to be maintained efficiently and continuously during the whole reaction. Assays were performed in a phosphate buffer with an initial $\mathrm{pH}$ of 6.0, with the use of a pH-stat in order to continuously regulate $\mathrm{pH}$. In comparison with the erlenmeyer flask, the bioreactor also allows a better stirring of incubation medium and a better aeration, which is important for this oxygen-dependent reaction.

The biotransformation of guttiferone $A$ and $C$ ( 1 and $\mathbf{6})$ by B. cactivora under these experimental conditions was studied and the proportions of obtained oxy-guttiferones are summarized in Table 2. We observed that the incubations of both guttiferone $A$ and $C$ with $B$. cactivora led to the formation of both 3,16- and 1,16-oxyguttiferone with a better yield for 3,16 ( 2 and 7 ) than for 1,16 ( 3 and 8). No oxy-guttiferone were observed in controls without guttiferone, showing that their formation results exclusively from biotransformations. In addition, as expected, biotransformation for both substrates are faster in bioreactor than in erlenmeyer flask. Indeed, after 3 days of incubation of guttiferone A (1), 75\% of the transformation in a bioreactor was observed, compared to only $35 \%$ in erlen. For guttiferone C (6), 39\% of transformation in bioreactors was observed compared to $20 \%$ in erlen. These preliminary assays showed the feasibility of a larger scale bioproduction of PPAPs xanthones. Thus, crude extracts of biotransformation (starting from $50 \mathrm{mg}$ of guttiferone A / C) in fermentor were chromatographed by preparative HPLC and led to $15.3 \mathrm{mg}$ of $\mathbf{2}(30 \%), 4.2 \mathrm{mg}$ of $\mathbf{3}(8,4 \%)$ and $13.8 \mathrm{mg}$ of $1(27 \%)$ and to $4.8 \mathrm{mg}$ of $7(9.6 \%) 6 \mathrm{mg}$ of $8(12 \%)$ and $4.8 \mathrm{mg}(9.5 \%)$ of 6 .

To our knowledge, the compounds $\mathbf{7}$ and $\mathbf{8}$ had not yet been described and their structural elucidations were investigated by spectral analysis (Table S1 and Fig. S1-S2 and S4-S11) and compared with known oxyguttiferones $A\left(2^{26}\right.$ and $\left.\mathbf{3}^{34}\right)$. Mass spectrometry data showed for compounds 7 a $\mathrm{m} / \mathrm{z} 691.3985[\mathrm{M}+\mathrm{Na}]^{+}$(Fig. S1)

Table 2 Biotransformations of guttiferone $\mathrm{A}$ and $\mathrm{C}$ by Bipolaris cactivora. Relative percent of substrates and products during the incubation at $27^{\circ} \mathrm{C}$ obtained by HPLC analysis of incubation media.

\begin{tabular}{|c|c|c|c|c|c|c|c|c|}
\hline \multirow[b]{3}{*}{ Time (days) } & \multicolumn{4}{|c|}{ Guttiferone A 1} & \multicolumn{4}{|c|}{ Guttiferone C 6} \\
\hline & \multicolumn{2}{|r|}{ Flask } & \multicolumn{2}{|c|}{ Fermentor } & \multicolumn{2}{|r|}{ Flask } & \multicolumn{2}{|c|}{ Fermentor } \\
\hline & 1 & $2 / 3$ (ratio) & 1 & 2 / 3 (ratio) & 6 & 7 / 8 (ratio) & 6 & 7 / 8 (ratio) \\
\hline 3 & 64.7 & 27.6 / 7.7 (3.6) & 25 & $58 / 17 \quad(3.4)$ & 79.5 & $18 / 2.5$ (7.2) & 41.6 & $43.2 / 15.2$ (2.8) \\
\hline 4 & $b$ & $b$ & - & - & $b$ & $b$ & 36 & $49.5 / 14.5$ (3.4) \\
\hline 5 & 54.7 & $36 / 9.3$ (3.9) & - & - & 76.5 & $19 / 4.5$ (1.6) & - & - \\
\hline 7 & 6.2 & 75.8 / 18 (4.2) & - & - & 33 & 54 / 13 (4.1) & - & - \\
\hline
\end{tabular}

a) after 2 hours of incubation-time b) not determined 

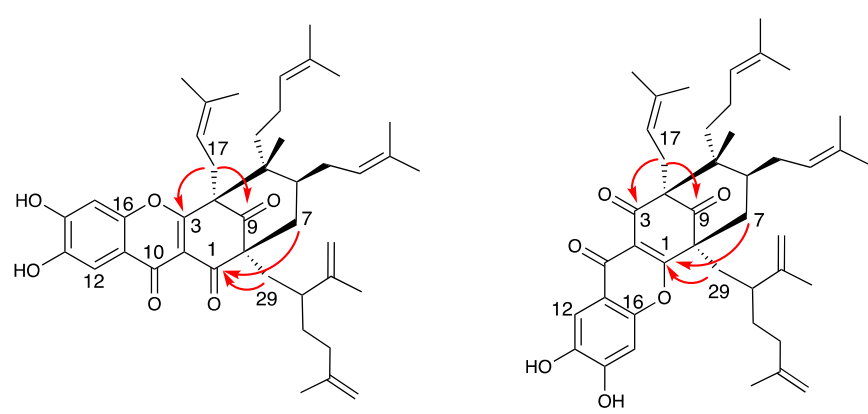

Fig. 2 Key HMBC correlation for oxy-guttiferones C 7 and $\mathbf{8}$.

and 8 a $m / z 667.3976$ [M-H]- (Fig. S2), corresponding to loss of two protons regarding guttiferone $\mathrm{C}$, in agreement with an oxidation reaction. For both new oxy Guttiferones $\mathrm{C} \mathbf{7}$ and $\mathbf{8}$, the cyclisation in position $\mathrm{C}-16$ on the catechol ring is confirmed by the NMR data showing singlets for $\mathrm{H}-12$ and $\mathrm{H}-15$ exhibiting no COSY correlation. In opposition, a C-12 cyclisation would have led doublets as obtained on our previous work on 1-12 and 3-12 oxyguttiferone A 4 and 5. ${ }^{27}$ In addition, the system (s, d, d) of the open catechol pattern has disappeared compared to the spectrum of guttiferone C 6 (Fig. S3), the starting material for this cyclisation. For compound 8, HMBC (figure 2) showed a strong correlation between proton $\mathrm{H} 7$ and carbon $\mathrm{C} 1$ at $178.9 \mathrm{ppm}$ corresponding to an enol whereas for compound 7 we observed a correlation between proton $\mathrm{H} 7$ and carbon C1 at 194.5 corresponding to a ketone. Conversely, for the protons $\mathrm{H} 17$, a correlation is observed with the carbon $\mathrm{C} 3$ at 176.7 ppm and at $194.9 \mathrm{ppm}$ for the compounds $\mathbf{7}$ and $\mathbf{8}$ respectively, as well as a correlation for each new compound with the ketone in position 9.

In addition to cyclization by plant enzyme(s), our results show that there may be two other possibilities for the formation of oxyguttiferones A ( $\mathbf{2}$ and $\mathbf{3}$ ), spontaneous cyclization as we observed at $\mathrm{pH}>7$ and cyclization involving endophyte microorganisms. We report relative proportions for cyclization metabolites in different $\mathrm{pH}$ buffers and in biotransformation, and we can compare them with proportions occurring in plant. Several observations are not consistent with spontaneous cyclization alone. First, while the ratio $\mathbf{2}$ to $\mathbf{3}$ in total plant's extract is $4: 1$, without microorganism, the cyclization of guttiferone $\mathrm{A}(\mathbf{1})$ gave exclusively $(\mathrm{pH} 7)$ or very largely $(\mathrm{pH} 8)$ the oxy-guttiferone 2 . It can be noted that the other two possible xanthones with 3,12 and 1,12 pattern were at date not reported as naturally occuring for oxy-guttiferone. Then, microbial cyclization of guttiferone A (1) in flask gave a ratio of $\mathbf{2}$ to $\mathbf{3}$ of $3.9: 1$ close enough to the ratio in total plant's extract $(4: 1){ }^{34}$ Finally, it has been shown that in plant, xanthone biosynthesis involved two CYP with alternative regioselective phenol couplings, each responsible for the formation of an isomer. It is therefore possible for us to suggest that endophytes are, at least partially, involved in the formation of these cyclization products. In fact, the role of endophytes in the formation of oxy-guttiferone $A$ can be important with regard to the presence of $B$. cactivora in several leaves. In view of these results and in accordance with this hypothesis, the question was why oxy-guttiferones $C$ were observed in very small amounts in the plant whereas guttiferone $\mathrm{C}$ is more abundant than guttiferone A. Indeed, oxy-guttiferones $C \mathbf{7}$ and $\mathbf{8}$ have been observed in $S$. globulifera latex only by LC/MS analysis using data obtained for

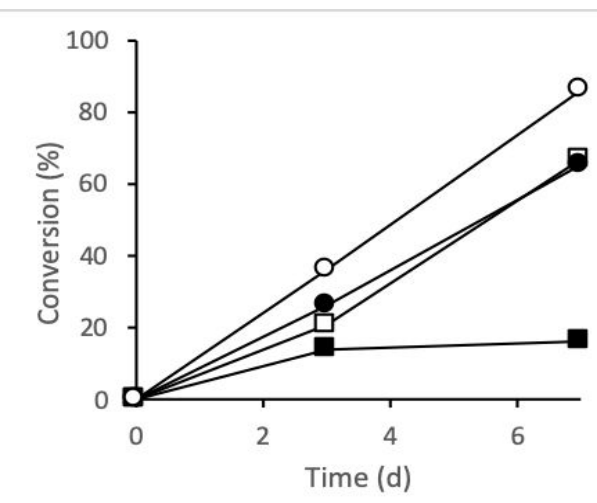

Fig. 3 Time course of the bioconversion of guttiferone $A$ alone ( $O$ ), in mixture with guttiferone $C(\bullet)$, guttiferone $C$ alone $(\square)$ and guttiferone $\mathrm{C}$ in mixture with guttiferone $\mathrm{A}($

microbial biotransformation products. These low quantities were surprising since the formation of oxy-guttiferones $C$ is observed by biotransformation. In order to explain this, we incubated together guttiferone A (1) and guttiferone C (6) with the microorganism. We showed the results obtained for the incubation of 1:1-mixture of guttiferone $A$ and $C(w / w)$ (Fig. 3 and Fig. S11). We observed that guttiferone $C(6)$ are weakly transformed during the incubation of mixture (16\% conversion after 7 days) in comparison with the incubation of guttiferone $C$ alone (65\% after 7 days). The bioconversion of guttiferone A (1) was hardly changed by the presence of guttiferone $C(6), 70 \%$ of biotransformation in mixture compared to $90 \%$ when guttiferone $A$ was incubated alone.

These results suggest that guttiferone $A(\mathbf{1})$ is better substrate than guttiferone $C(\mathbf{6})$, and the presence of $\mathbf{1}$ influences microbial biotransformation of 6 through a competitive inhibition mechanism. According to our hypothesis, this explains that only small amounts of oxy-guttifeones $\mathrm{C}$ have been observed in the plant.

Different levels of endophyte/plant partnership in the production of secondary metabolites can be distinguished. ${ }^{35}$ On the one hand, endophytes can transform plant metabolites in order to detoxify the host plant's defense compounds, like 6-methoxy-2benzoxazolinone (MBOA) and 2-benzoxazolinone (BOA). ${ }^{36}$ And on the other hand, it has recently been shown that the fungus Paraconiothyrium variabile transforms a glycosylated flavonoid into an aglycone that promotes the hyphal growth of germinated spores. ${ }^{37}$ Endophytes may have a role in the formation of metabolites isolated from host plants, and this may involve one or more steps of the biosynthetic pathway. ${ }^{38}$ A study of fungal endophytes of Vanilla planifolia suggests a contribution of microbial biotransformation to the complexity of vanilla flavours. ${ }^{39}$ Regarding oxy-guttiferones, the contribution of our isolated endophytic fungus is limited, perhaps exclusively at the last step, since guttiferones A and $\mathrm{C}$ were not detected in the culture media. However, it cannot be ruled out that they are produced by the plant. For example, xanthones that do not belong to the PPAPs family are produced by Hypericum, and their biosynthesis in $\mathrm{H}$. perforatum has recently been shown to involve a cytochrome P450. ${ }^{40}$

\section{Conclusions}


In conclusion, these results show that our approach of isolating endophytes and screening them on their ability to biotransform secondary metabolites of the host plant is relevant. Unlike a selection on microorganisms from culture collections, this bioguided approach allowed us to select active microorganisms with very few assays. In addition, this approach allows the production of metabolites present in the host plant extracts but also new products by applying biotransformation to other secondary metabolites of the plant. Finally, all the obtained results are consistent with an intervention of the endophytic microorganism in the formation of oxy-guttiferones in the plant.

\section{Experimental Section}

\section{Materials and methods}

Guttiferones A (1) and C (6) were obtained as described. ${ }^{24}$ Trifluoroacetic acid and formic acid were of reagent grade from Fluka. Gradient grade HiPersSolv acetonitrile from VWR was used. HPLC analysis was performed on Gilson system (pump 305, pump 306 , gradient dynamic mixer $811 \mathrm{~B}$ and autoinjector 234) with an Agilent C18 column $(21.2 \times 150 \mathrm{~mm}, 5 \mu \mathrm{m})$. The system was controlled and the results were analysed by Unipoint Gilson software. Column was eluted with an appropriate solvent system at a flow of 1.0 $\mathrm{mL} / \mathrm{min}$ : (solvent A: water, $0.1 \%$ trifluoroacetic acid; solvent B: $50 \%$ water $/ 50 \%$ acetonitrile, $0.1 \%$ trifluoroacetic acid) $0-5 \mathrm{~min}$ (isocratic $90 / 10$ ), 5-8 min (gradient up to 50/50), 8-15 min (gradient up to 20/80), 15-20 min (isocratic 20/80). The detection was at $240 \mathrm{~nm}$. Preparative HPLC was performed on an Agilent system, using an Agilent PrepHT XDB-C18 column ( $21.2 \times 150$ mm; 5 mm; USA). Sample was injected and separated using the same gradient program for HPLC analysis (gradient $45 \mathrm{~mL} / \mathrm{min}$ ). Optical rotations were measured with a Perkin-Elmer 341 polarimeter. HRMS measurements were performed on a Waters QTOF I mass instrument. 1D and 2D NMR spectra were monitored on a Brucker NMR $400 \mathrm{MHz}$ and $100 \mathrm{MHz}$ instruments using CD3OD ([ ${ }_{\mathrm{H}} 3.31$ and ]$\left._{C} 49.0\right)$ as solvent. Chemical shifts $(\delta)$ are reported in parts per million (ppm), and coupling constants $(J)$ are given in hertz $(\mathrm{Hz})$.

\section{Isolation and identification of endophytic fungal strains}

Fresh Symphonia globulifera leaves were harvested at Macouria, French Guiana in 2012, washed in water less than two hours after collection and surface-sterilized by successive dips in $95 \%$ ethanol (15 seconds), 0.5\% sodium hypochlorite solution (120 seconds) and in $70 \%$ ethanol (120 seconds). Leaves were then cut in square sections with sterile single-use scalpel blade. Sections were laid in Petri dishes containing PDA (Potato-Dextrose-Agar) medium and agar plates incubated in a cultivation chamber maintained at $27^{\circ} \mathrm{C}$. After several days, sections' margins showed microorganisms development, and transplantations were performed in order to obtain pure cultures.

Genomic DNA was extracted from fresh mycelium grown for 5 days on Malt Agar. Extractions were performed using the DNeasy Plant Mini Kit (Qiagen, Ltd., Crawley, UK) following the manufacturer's instructions. ITS plus the $5^{\prime}$ end of 285 rDNA were amplified using primers sets ITS4/ITS5 ${ }^{41}$ and LROR/LR6 (Vilgalys, Duke University, Durham, North Carolina, United States) respectively. PCR amplifications were performed using a BioRad DNA Engine Peltier Thermal cycler with 30 cycles of $30 \mathrm{~s}$ at $94^{\circ} \mathrm{C}, 30 \mathrm{~s}$ at $55^{\circ} \mathrm{C}$ (for ITS4/ITS5 primers) or $50^{\circ} \mathrm{C}$ (for LROR/LR6 primers), $40 \mathrm{~s}$ at $72^{\circ} \mathrm{C} ; 10$ min at $72^{\circ} \mathrm{C}$, in a $25 \mu \mathrm{L}$ reaction mix, containing $12.5 \mu \mathrm{L}$ genomic DNA (dilution: $10^{-2}$ after extraction), $5 \mu \mathrm{L}$ PCR Direct Loading Buffer with
MgCl2 (Q-Biogen), $0.5 \mu \mathrm{L}$ dNTPs (6.25 mM, dNTP Mix, Q-Biogen), 1 $\mu \mathrm{L}$ of each $10 \mu \mathrm{M}$ primer (Eurogentec), $0.125 \mu \mathrm{L}$ Taq DNA Polymerase (Q-Biogen, 5 units $/ \mu \mathrm{L}$ ), and $4.875 \mu \mathrm{L}$ sterile water. PCR products were purified and sequenced by Genoscreen (Lille, France) in both directions to confirm the accuracy of each sequence. Sequences were assembled with CodonCode Aligner v. 3.7.1 (Codon Code Corporation), checked by visual inspection of the chromatograms and edited if necessary. Sequences were identified using the BLAST option at http://blast.st-va.ncbi.nlm.nih.gov/Blast.cgi. Best hits were carefully examined to attribute species names ( $\geq 97 \%$ of sequence similarities). Isolate has been deposited at the fungal culture collection of the MNHN under the number LCP6370.

\section{General procedure for analytical biotransformations}

Microorganisms were maintained on agar slant culture tubes (in g. $\mathrm{L}^{-1}$ glucose 20, bactopeptone 5 , yeast extract 5 , malt extract 5 and agar 20) sterilized $15 \min 121^{\circ} \mathrm{C}$. Biomasses were obtained by culture of isolated strains in liquid culture media containing (g.L $\left.\mathrm{L}^{-1}\right)$ glucose 16 , yeast extract 4 , malt extract 10 , and soybean peptones 5 (YMS medium). Erlenmeyer flasks were incubated at $27^{\circ} \mathrm{C}$ under efficient stirring (130-160 rpm) for 48 to 72 hours. Recovered biomass by gauze-filtration $(21 \mathrm{~g})$ was placed in an Erlenmeyer flask $(100 \mathrm{~mL})$ and resuspended in potassium phosphate buffer $0.066 \mathrm{M}, \mathrm{pH} 6.0(20 \mathrm{~mL})$. Substrates were then added to the suspension as a DMF solution $(60 \mu \mathrm{L})$ to a final concentration of $0.1 \mathrm{mg} \cdot \mathrm{mL}^{-1}$. Incubations were performed at $25-30^{\circ} \mathrm{C}$ with stirring $(150 \mathrm{rpm})$ and the reaction was monitoring via HPLC analysis. Controls without microorganisms or without guttiferone were performed and analysed using the same protocol.

\section{Preparative biotransformations}

Reactions were conducted in reactor containing potassium phosphate buffer $0.06 \mathrm{M}, \mathrm{pH} 6.0(400 \mathrm{~mL})$ at $27^{\circ} \mathrm{C}$ and under agitation (150 rpm). Guttiferone is added (guttiferone A $60 \mathrm{mg}$, guttiferone $\mathrm{C} 50 \mathrm{mg}$ ) in DMF $(1.5 \mathrm{~mL})$. Then, $85 \mathrm{~g}$ of fungal biomass are added, and $50 \mathrm{~mL}$ buffer added again in order to obtain a total volume of $500 \mathrm{~mL}$. Filtered air is insufflated continuously (10 $\mathrm{mL} / \mathrm{min}$ ). $\mathrm{pH}$ is adjusted automatically by addition of $0.1 \mathrm{M} \mathrm{HCl}$ solution as needed in order to maintain it below 6.20 under constant monitoring with a $\mathrm{pH}$-probe. In the end, suspension was gauzefiltered and aqueous supernatant recovered, acidified with $\mathrm{HCl} 1 \mathrm{M}$, then extracted with ethyl acetate several times. Biomass pellet was resuspended in an equivalent volume of methanol and sonicated for 10 minutes. After centrifugation, the extraction was repeated 2 times on the pellet, and the pooled methanolic extracts was evaporated to dryness with a rotary evaporator. Dry residue was resuspended in an ethyl acetate/water mixture under stirring. Once recovered, organic phase was then pooled with the one from aqueous supernatant extraction, dried over magnesium sulfate, then evaporated to dryness with a rotary evaporator. Crude extract was purified by HPLC chromatography.

3,16 oxy-guttiferone $\mathbf{A}(\mathbf{2})^{34}$ was eluted at $16 \mathrm{~min}$, and obtained as yellow oil, $38.0 \mathrm{mg}(63 \%)$

1,16-oxy-guttiferone $\mathbf{A}(\mathbf{3})^{26}$ was eluted at $13 \mathrm{~min}$, and obtained as yellow oil, $10.1 \mathrm{mg}(16.6 \%)$.

3,16 oxy-guttiferone $C(7)$ ( $\left(t_{R} 21 \mathrm{~min}\right)$ was obtained as yellow oil, 6.0 $\mathrm{mg}(12 \%) .[\alpha]_{\mathrm{D}}{ }^{20}-18$ (2.79, $\left.\mathrm{MeOH}\right)$. Exact mass: $\left[\mathrm{M}+\mathrm{Na}^{+}\right]^{+} 691.3985$ (calcd for $\left.\mathrm{C}_{43} \mathrm{H}_{56} \mathrm{O}_{6} \mathrm{Na}^{+} 691,3969\right)$. NMR ${ }^{1} \mathrm{H}\left(400 \mathrm{MHz}, \mathrm{CD}_{3} \mathrm{OD}\right), \delta$ (ppm) : 7.44 (s, 1H, H-12), $6.94(\mathrm{~s}, 1 \mathrm{H}, \mathrm{H}-15), 5.10(\mathrm{t}, \mathrm{J}=7 \mathrm{~Hz}, 1 \mathrm{H}, \mathrm{H}-$ 40), $4.82(\mathrm{~m}, 1 \mathrm{H}, \mathrm{H}-25), 4.67$ (m, 1H, H-18), 4.64 (s, 1H, H-37), 4.61 (s, 
$1 \mathrm{H}, \mathrm{H}-37), 4.47$ (s, 1H, H-32), $4.38(\mathrm{~m}, 1 \mathrm{H}, \mathrm{H}-32), 3.01-2.77(\mathrm{~m}, 2 \mathrm{H}, \mathrm{H}$ 17), 2.67 (heptuplet, J $=5 \mathrm{~Hz}, 1 \mathrm{H}, \mathrm{H}-30), 2.24-2.12(\mathrm{~m}, 4 \mathrm{H}, \mathrm{H}-7, \mathrm{H}-29)$, 2.00-1.78 (m, 10H, H-6, H-23, H-24, H-35, H-39), 1.77 (s, 3H, H-28), $1.69(\mathrm{~s}, 3 \mathrm{H}, \mathrm{H}-38), 1.67$ (s, 3H, H-27), 1.60 (s, 6H, H-42, H-33), 1.57 (s, $3 \mathrm{H}, \mathrm{H}-43), 1.43(\mathrm{~s}, 3 \mathrm{H}, \mathrm{H}-20), 1.38(\mathrm{~s}, 2 \mathrm{H}, \mathrm{H}-34), 1.33$ (s, 3H, H-21), 1.28 (s, 3H, H-22). NMR ${ }^{13} \mathrm{C}\left(100 \mathrm{MHz}, \mathrm{CD}_{3} \mathrm{OD}\right), \delta$ (ppm): 208.7 (C-9), 194.5 (C-1), 176.7 (C-3), 173.7 (C-10), 154.7 (C-16), 151.3 (C-14), 150.2 (C-31), 149.5 (C-36), 146.9 (C-13), 135.9 (C-19), 133.7 (C-26), 133.0 (C-41), 125.3 (C-25), 125.0 (C-40), 121.3 (C-2), 120.3 (C-18), 118.2 (C-11), 114.7 (C-32), 110.4 (C-37), 109.6 (C-12), 103.9 (C-15), 63.3 (C-4), 53.4 (C-6), 51.5 (C-5), 44.8 (C-7), 44.1 (C-30), 41.0 (C-8), 38.8 (C-29), 36.8 (C-35), 36.5 (C-23), 32.5 (C-34), 30.3 (C-24), 26.5 (C17), 26.1 (C-20), 26.0 (C-27), 25.9 (C-42), 24.1 (C-39), 22.6 (C-38), 20.4 (C-22), 18.7 (C-21), 18.0 (C-28), 17.9 (C-33), 17.8 (C-43)

1,16-oxy-guttiferone $C(8)\left(t_{R} 18 \mathrm{~min}\right)$ was obtained as yellow oil, 4.8 mg (9.6\%). $[\alpha]_{D}{ }^{20}+47(0.75, \mathrm{MeOH})$. Exact mass: $\left[\mathrm{M}-\mathrm{H}^{+}\right]^{-} 667.3976$ (calcd for $\left.\mathrm{C}_{43} \mathrm{H}_{55} \mathrm{O}_{6}{ }^{-} 667,4004\right)$, NMR ${ }^{1} \mathrm{H}\left(400 \mathrm{MHz}, \mathrm{CD}_{3} \mathrm{OD}\right), \delta(\mathrm{ppm})$ : $7.44(\mathrm{~s}, 1 \mathrm{H}, \mathrm{H}-12), 6.91(\mathrm{~s}, 1 \mathrm{H}, \mathrm{H}-15), 5.11(\mathrm{t}, \mathrm{J}=7 \mathrm{~Hz}, 1 \mathrm{H}, \mathrm{H}-40), 4.76$ (m, 2H, H-25 and H-18), $4.61(\mathrm{~s}, 1 \mathrm{H}, \mathrm{H}-37), 4.58$ (s, 1H, H-37), 4.16 (s, $1 \mathrm{H}, \mathrm{H}-32), 4.09(\mathrm{~m}, 1 \mathrm{H}, \mathrm{H}-32), 2.65$ (t, J=8 Hz, 2H, H-17), 2.44 (d, J=14 $\mathrm{Hz}, 1 \mathrm{H}, \mathrm{H}-7), 2.30$ ( $\mathrm{m}, 2 \mathrm{H}, \mathrm{H}-29$ and $\mathrm{H}-30), 2.05$ (dd, J=14 Hz and $7 \mathrm{~Hz}$, $1 \mathrm{H}, \mathrm{H}-7$ ), 2.01-1.75 (m, 8H, H-6, H-29, H-35, H-24, H-39), 1.73 (s, 3H, $\mathrm{H}-38), 1.70(\mathrm{~s}, 3 \mathrm{H}, \mathrm{H}-42), 1.67(\mathrm{~s}, 3 \mathrm{H}, \mathrm{H}-33), 1.63(\mathrm{~m}, 2 \mathrm{H}, \mathrm{H}-34), 1.61$ $(\mathrm{s}, 3 \mathrm{H}, \mathrm{H}-22), 1.59$ (s, 3H, H-43), $1.56(\mathrm{~s}, 3 \mathrm{H}, \mathrm{H}-20), 1.51$ (s, 3H, H-27), 1.14 (s, 3H, H-21). NMR ${ }^{13} \mathrm{C}\left(100 \mathrm{MHz}, \mathrm{CD}_{3} \mathrm{OD}\right), \delta$ (ppm): 208.4 (C-9), 194.9 (C-3), 178.9 (C-1), 174.1 (C-10), 154.6 (C-16), 151.0 (C-14), 148.1 (C-31), 147.0 (C-36), 146.5 (C-13), 135.4 (C-19), 133.8 (C-26), 132.9 (C-41), 125.1 (C-25), 124.8 (C-40), 121.0 (C-2), 119.9 (C-18), 118.8 (C-11), 112.9 (C-32), 110.7 (C-37), 109.6 (C-12), 104.1 (C-15), 73.6 (C-4), 57.0 (C-6), 53.7 (C-5), 44.7 (C-30), 42.4 (C-7), 40.3 (C-8), 37.7 (C-29), 36.3 (C-35), 36.2 (C-23), 32.9 (C-34), 30.4 (C-24), 26.5 (C17), 26.2 (C-20), 25.9 (C-27), 25.7 (C-42), 24.2 (C-39), 22.6 (C-38), 20.4 (C-22), 18.7 (C-21), 18.5 (C-28), 17.9 (C-33), 17.7 (C-43)

\section{Conflicts of interest}

There are no conflicts to declare

\section{Acknowledgements}

This work was funded by Université Paris Descartes Sorbonne Paris Cité (grant to PM, KC and YF) which are gratefully acknowledged.

\section{Notes and references}

1. R. Azerad, in Biocatalysis in the Pharmaceutical and Biotechnology Industries., ed. R. Patel, CRC. Press, Boca Raton 2006, pp. 273-297.

2. (a)R. K. Venisetty and V. Ciddi, Curr. Pharm. Biotechnol., 2003, 4, 153-167; (b)M.-E. F. Hegazy, T. A. Mohamed, A. I. El Shamy, A.E.-H. H. Mohamed, U. A. Mahalel, E. H. Reda, A. M. Shaheen, W. A. Tawfik, A. A. Shahat, K. A. Shams, N. S. Abdel-Azim and F. M. Hammouda, J. Adv. Res., 2015, 6, 17-33.

3. (a)M. P. C. Marques, S. Magalhaes, J. M. S. Cabral and P. Fernandes, J. Biotechnol., 2009, 141, 174-180; (b)C. Marvalin and R. Azerad, Xenobiotica, 2011, 41, 175-186; (c)J. Z. Baboo, J. L. Galman, G. J. Lye, J. M. Ward, H. C. Hailes and M. Micheletti, Biotechnology Progress, 2012, 28, 392-405; (d)M. P. C. Marques and P. Fernandes, in Microbial Steroids: Methods and Protocols, eds. J. L. Barredo and I. Herraiz, 2017, vol. 1645, pp. 167-176.
4. (a)Y. Fromentin, P. Grellier, S. Michel, D. Buisson and M. C. Lallemand, Planta Med., 2012, 78, 1075-1075; (b)R. Joyeau, M. Planchon, J. Abessolo, K. Aissa, C. Bance and D. Buisson, J. Mol. Cat. B-Enz, 2013, 85-86, 65-70; (c)C. Laurence, M. Rivard, T. Martens, C. Morin, D. Buisson, S. Bourcier, M. Sablier and M. A. Oturan, Chemosphere, 2014, 113, 193-199.

5. C. Werner, O. Petrini and M. Hesse, Fems Microbiol. Lett., 1997, 155, 147-153.

6. H. Shibuya, C. Kitamura, S. Maehara, M. Nagahata, H. Winarno, P. Simanjuntak, H. S. Kim, Y. Wataya and K. Ohashi, Chem Pharm Bull (Tokyo), 2003, 51, 71-74.

7. A. Majeed, M. Majeed, N. Thajuddin, S. Arumugam, F. Ali, K. Beede, S. J. Adams and M. Gnanamani, Amb Express, 2019, 9.

8. G. Ekiz, S. Duman and E. Bedir, Phytochem., 2018, 151, 91-98.

9. Z. U. Din, L. S. de Medeiros, L. M. Abreu, L. H. Pfenning, D. B. L. Jymeni and E. Rodrigues, Bioorg. Chem., 2018, 78, 436-443.

10. (a)Y. M. Ying, W. G. Shan and Z. J. Zhan, J. Nat. Prod., 2014, 77, 2054-2059; (b)Y. M. Ying, Y. L. Xu, H. F. Yu, C. X. Zhang, W. Mao, C. P. Tong, Z. D. Zhang, Q. Y. Tang, Y. Zhang, W. G. Shan and Z. J. Zhan, Fitoterapia, 2019, 138.

11. Z. J. Zhan, T. Tian, Y. L. Xu, H. F. Yu, C. X. Zhang, Z. D. Zhang, Q. Y. Tang, W. G. Shan and Y. M. Ying, Chem. Biodivers., 2019, 16, e1900299.

12. (a)P. Arunrattiyakorn, N. Suwannasai, T. Aree, S. Kanokmedhakul, H. Ito and H. Kanzaki, J. Mol. Catal. B: Enzym., 2014, 102, 174-179; (b)P. Arunrattiyakorn, M. Kuno, T. Aree, S. Laphookhieo, T. Sriyatep, H. Kanzaki, M. A. Garcia Chavez, Y. A. Wang and R. J. Andersen, J. Nat. Prod., 2018, 81, 2244-2250.

13. S.-L. Luo, L.-Z. Dang, J.-F. Li, C.-G. Zou, K.-Q. Zhang and G.-H. Li, Chem. Biodivers., 2013, 10, 2021-2031.

14. A. Kumar and A. Ahmad, Biocatal. Biotransform., 2013, 31, 8993.

15. D. Qin, W. Shen, T. Gao, S. Zuo, H. Song, J. Xu, B. Yu, Y. Peng, J. Guo, W. Tang and J. Dong, Phytochem., 2020, 174, 112335.

16. (a)K. Cottet, G. Genta-Jouve, Y. Fromentin, G. Odonne, C. Duplais, O. Laprevote, S. Michel and M. C. Lallemand, Phytochem., 2014, 108, 102-108; (b)K. Cottet, E. Kouloura, M. Kritsanida, J. D. Wansi, G. Odonne, S. Michel, M. Halabalaki and M. C. Lallemand, Phytochem. Lett., 2017, 20, 309-315.

17. Y. Fromentin, K. Cottet, M. Kritsanida, S. Michel, N. GaboriaudKolar and M. C. Lallemand, Planta Med., 2015, 81, 95-107.

18. K. R. Gustafson, J. W. Blunt, M. H. G. Munro, R. W. Fuller, T. C. Mckee, J. H. Cardellina, J. B. Mcmahon, G. M. Cragg and M. R. Boyd, Tetrahedron, 1992, 48, 10093-10102.

19. R. B. Williams, J. Hoch, T. E. Glass, R. Evans, J. S. Miller, J. H. Wisse and D. G. I. Kingston, Planta Med., 2003, 69, 864-866.

20. F. Abe, S. Nagafuji, H. Okabe, H. Akahane, E. Estrada-Muniz, M. Huerta-Reyes and R. Reyes-Chilpa, Biological \& Pharmaceutical Bulletin, 2004, 27, 141-143.

21. S. Ngouela, B. N. Lenta, D. T. Noungoue, J. Ngoupayo, F. F. Boyom, E. Tsamo, J. Gut, P. J. Rosenthal and J. D. Connolly, Phytochem., 2006, 67, 302-306.

22. B. N. Lenta, C. Vonthron-Senecheau, B. Weniger, K. P. Devkota, J. Ngoupayo, M. Kaiser, Q. Naz, M. I. Choudhary, E. Tsamo and N. Sewald, Molecules, 2007, 12, 1548-1557.

23. K. S. T. Dias, J. P. Januario, J. L. D' Dego, A. L. T. Dias, M. H. dos Santos, I. Camps, L. F. L. Coelho and C. Viegas, Bioorganic \& Medicinal Chemistry, 2012, 20, 2713-2720.

24. K. Cottet, Y. Fromentin, M. Kritsanida, R. Grougnet, G. Odonne, C. Duplais, S. Michel and M. C. Lallemand, Planta Med., 2015, 81, 1604-1608. 


\section{Journal Name ARTICLE}

25. Y. Fromentin, Thèse de doctorat, Université Paris Descartes, 2013.

26. Y. Fromentin, P. Grellier, J. D. Wansi, M. C. Lallemand and D. Buisson, Org. Lett., 2012, 14, 5054-5057.

27. P. Menelle, K. Cottet, Y. Fromentin, T. Gaslonde, F. H. Poree, D. Buisson and M. C. Lallemand, Tetrahedron Lett., 2017, 58, 48764879.

28. A. E. Arnold, D. A. Henk, R. L. Eells, F. Lutzoni and R. Vilgalys, Mycologia, 2007, 99, 185-206.

29. D. S. Manamgoda, A. Y. Rossman, L. A. Castlebury, P. W. Crous, H. Madrid, E. Chukeatirote and K. D. Hyde, Stud. Mycol., 2014, DOI: 10.1016/j.simyco.2014.10.002, 221-288.

30. J. E. T. Ateba, R. M. K. Toghueo, A. F. Awantu, B. M. Mba'ning, S. Gohlke, D. Sahal, E. Rodrigues, E. Tsamo, F. F. Boyom, N. Sewald and B. N. Lenta, J. Fungi, 2018, 4, 70.

31. J. E. Atkinson and J. R. Lewis, Chem. Commun., 1967, DOI: 10.1039/c1967000803a, 803.

32. S. Peters, W. Schmidt and L. Beerhues, Planta, 1998, 204, 64-69.

33. X. J. Zhang, S. F. Ye, Y. Zhang, H. Y. Meng, M. Q. Zhang, W. L. Gao and Q. D. You, Synthetic Communications, 2012, 42, 2952-2958.

34. K. Cottet, A. Neudorffer, M. Kritsanida, S. Michel, M. C. Lallemand and M. Largeron, J. Nat. Prod., 2015, 78, 2136-2140.
35. J. Ludwig-Muller, Biotechnol. Lett., 2015, 37, 1325-1334.

36. (a)M. Zikmundova, K. Drandarov, L. Bigler, M. Hesse and C. Werner, Appl. Environ. Microbiol., 2002, 68, 4863-4870; (b)M. Saunders and L. M. Kohn, Appl. Environ. Microbiol., 2008, 74, 136-142.

37. Y. Tian, S. v. Amand, D. Buisson, C. Kunz, F. B. Hachette, J. I. Dupont, B. Nay and S. Prado, Phytochem., 2014, 108, 95-101.

38. D. Qin, L. Wang, M. J. Han, J. Q. Wang, H. C. Song, X. Yen, X. X. Duan and J. Y. Dong, Frontiers in Microbiology, 2018, 9.

39. S. Khoyratty, T. L. Palama, H. Kodja, S. Khoyratty, Y. H. Choi, H. K. Kim, R. Verpoorte, S. Khoyratty, T. L. Palama, J. Dupont, S. Lacoste, T. L. Palama, B. Payet, M. Fouillaud, M. Grisoni and H. Kodja, BMC Plant Biol., 2015, 15, 142.

40. N. Tocci, M. Gaid, F. Kaftan, A. K. Belkheir, I. Belhadj, B. Y. Liu, A. Svatos, R. Hansch, G. Pasqua and L. Beerhues, New Phytologist, 2018, 217, 1099-1112.

41. T. J. White, T. Bruns, S. Lee and J. Taylor, in PCR Protocols, eds. M. A. Innis, D. H. Gelfand, J. J. Sninsky and T. J. White, Academic Press, San Diego, 1990, DOI: https://doi.org/10.1016/B978-0-12372180-8.50042-1, pp. 315-322. 